\title{
Effects of simulated fish predation on small colonies of massive Porites spp. and Pocillopora meandrina
}

\author{
Caitlin M. Cameron ${ }^{1,2, *}$, Peter J. Edmunds ${ }^{1}$ \\ ${ }^{1}$ Department of Biology, California State University, 18111 Nordhoff Street, Northridge, California 91330-8303, USA \\ ${ }^{2}$ Rosenstiel School of Marine and Atmospheric Science, University of Miami, 4600 Rickenbacker Causeway, \\ Miami, Florida 33149, USA
}

\begin{abstract}
The effects of corallivory on small colonies of massive Porites spp. $(<5 \mathrm{~cm}$ diameter) and Pocillopora meandrina ( $<7 \mathrm{~cm}$ high) were explored in situ on shallow reefs in Moorea, French Polynesia. Experiments were conducted to test the hypothesis that corals respond equally to damage caused by single bites of fishes belonging to 3 functional feeding guilds defined as excavators, scrapers, and browsers, which damage corals in different ways. While recovering from damage, massive Porites spp. grew 24 to $43 \%$ faster by weight than $P$. meandrina, and lesions caused by scraping and browsing healed more rapidly on $P$. meandrina than on massive Porites spp.; lesions caused by excavation healed more rapidly on massive Porites spp. than on $P$. meandrina. These results suggest that the effects of fish corallivores differ between coral taxa, with the contrasting effects potentially arising from differences in skeletal structure, corallum morphology, and mode of corallivore feeding.
\end{abstract}

KEY WORDS: Scleractinia $\cdot$ Damage $\cdot$ Recovery $\cdot$ Fish predation $\cdot$ Porites $\cdot$ Pocillopora

\section{INTRODUCTION}

Although corallivory by fishes is a well-known chronic disturbance affecting reef corals (Bak et al. 1977, Jayewardene et al. 2009, Rotjan \& Dimond 2010, Cole et al. 2011, Cole \& Pratchett 2011), there have been few attempts to compare the effects of different types of fish corallivores on the growth of multiple coral taxa. Such studies are important because the effects of fish corallivory have strong ecological implications through the consequences on growth and reproduction of coral tissue and skeleton (reviewed in Rotjan \& Lewis 2005, 2008, 2009, Edmunds \& Lenihan 2010). While corals can recover from many kinds of corallivory (Rotjan \& Lewis 2008, Jayewardene et al. 2009), their physiological responses to these localized disturbances vary (Hall 1997, Meesters et al. 1997), potentially because of differences in the capacity for tissue regeneration (Hall 1997, Meesters et al. 1997), colony size, corallum morphology, tissue thickness, and polyp density (Hall 1997).

Following damage to corals by fish corallivores, the amount of skeleton that needs to be repaired depends on the size of the bite and the depth to which the bite penetrates the skeleton. Perforate skeletons are more readily excavated than imperforate skeletons, and therefore a fish corallivore is more likely to bite deeper into the skeletons of perforate corals (e.g. Porites spp.) compared to the skeletons of imperforate corals (e.g. Pocillopora spp.). Additionally, corallum morphology can affect the impact of fish bites, with branching corals like Pocillopora spp. and Acropora spp. subject to complete branch removal by a single fish bite, whereas massive colonies like those of many Porites spp. and Montastraea spp. typically have only 
smaller bites excavated from their surface. Once a coral is damaged, the repair of tissue and skeleton requires metabolic resources in the form of carbon, and these are typically translocated from undamaged portions of the coral to the site of demand (Oren et al. 1997a,b, 2001). Thus, bigger colonies with more tissue and larger resources, or colonies with a strong capacity to translocate resources across the colony surfaces, should be able to recover faster than small colonies when both are damaged equally.

Fish corallivores feed on corals in different ways that separate them into 3 feeding guilds: browsers such as butterflyfish pluck tissue from polyps without damaging the skeleton (Hiatt \& Strasburg 1960); scrapers such as parrotfish have fused jaws that scrape the surface of corals, damaging tissue and some of the skeleton; and excavators such as some parrotfish and some tetraodonts (pufferfish) exert more force while biting than scrapers and are capable of severely damaging coral tissue and skeleton (Hiatt \& Strasburg 1960). To heal the damage that fish corallivory creates, coral tissue must regenerate to occupy the void and 'close' the lesion, and if the damage includes the removal of skeleton, complete healing also requires new skeletal growth $\left(\mathrm{CaCO}_{3}\right.$ and organic matrix). The size, shape, and position of lesions on a coral colony also affects healing (Bak \& Steward-Van Es 1980, Meesters et al. 1992, Oren et al. 1997a), with large lesions taking longer to heal and having a greater chance of healing incompletely than small lesions (Bak \& Steward-Van Es 1980, Oren et al. 1997a) and circular lesions healing faster than rectangular lesions because they have proportionately larger perimeters from which regeneration can occur (Oren et al. 1997a). In addition to the biological factors affecting rates of healing, physical factors such as temperature and water flow also modulate the rate of recovery from localized damage (Edmunds \& Lenihan 2010, Lenihan \& Edmunds 2010).

The present study was conducted in the back reef of Moorea, French Polynesia, where massive Porites spp. and Pocillopora spp. are common (Adjeroud et al. 2009, Pratchett et al. 2011) and provide the food favored by many corallivorous fishes (Berumen \& Pratchett 2006, Cole et al. 2008, Rotjan \& Lewis 2008, Jayewardene et al. 2009, Pratchett 2013). Massive Porites spp. and Pocillopora meandrina were used for experiments testing the effects of different types of fish corallivory on coral healing because they differ in a suite of features associated with skeletogenesis. Notably, in branching corals like $P$. meandrina, growth predominantly is apical (Allemand \& BenazetTambutte 1996), whereas in massive corals, growth occurs across the colony surface (Barnes \& Devereux 1988). Associated with this difference, pocilloporids typically grow faster $\left(28 \mathrm{~mm} \mathrm{yr}^{-1}\right.$; Jackson 1979, Edmunds 2005) than massive Porites spp. (13 $\mathrm{mm} \mathrm{yr}^{-1}$; Lough \& Barnes 2000), and pocilloporids heal rapidly following damage (Ayre et al. 1997, Hall 1997, Lenihan \& Edmunds 2010). The causes of the differences in healing rates between these taxa are unknown but may be related to the thickness of the tissue and skeletal porosity, both of which are well developed in massive Porites spp. (Stimson 1987, Barnes \& Lough 1992, Edmunds 2008) but not in Pocillopora spp. (Tricas 1989, Lenihan \& Edmunds 2010).

We simulated the damage caused to corals by fish corallivores belonging to browser, scraper, and excavator functional feeding guilds and used a $21 \mathrm{~d}$ field experiment to test the hypothesis that small massive Porites spp. and branches of Pocillopora meandrina would heal and grow at equal rates following damage. Small colonies of both taxa limited the impact of collecting on the coral communities, and by using small and young colonies of massive Porites spp., we focused on a life stage that is important in structuring coral communities (Vermeij $\&$ Sandin 2008). From this point on, massive Porites spp. and Pocillopora meandrina are referred to as 'Porites' and 'Pocillopora', respectively.

\section{MATERIALS AND METHODS}

This study was conducted during April and May 2009 in the back reef along the north shore of Moorea $\left(149^{\circ} 50^{\prime} \mathrm{W}, 17^{\circ} 30^{\prime} \mathrm{S}\right)$. To test the hypothesis that corals respond equally to corallivory attributed to fishes representing 3 feeding guilds, 32 small colonies of Porites and branches of Pocillopora were damaged in one of 3 ways, simulating lesions created by corallivorous fishes in the browsing, scraping, and excavating guilds. Damaged corals were returned to the reef for recovery within small cages $(32 \times 16 \times 14 \mathrm{~cm}$ with $2 \times 2 \mathrm{~cm}$ mesh) to prevent further damage from fishes, after which they were assessed for healing.

A separate experiment serving as a procedural control tested the effects of cages on corals, assuming these could arise from decreased flow and light within the mesh of the cages. Undamaged Porites $(n=20)$ were allocated to either a caged $(n=10)$ or an uncaged $(n=10)$ group in the back reef and left for the duration of the damage experiment $(21 \mathrm{~d})$; cages were attached to cinderblocks at $3 \mathrm{~m}$ depth. At the end of this period, growth of caged and uncaged corals was assessed using buoyant weighing, and 


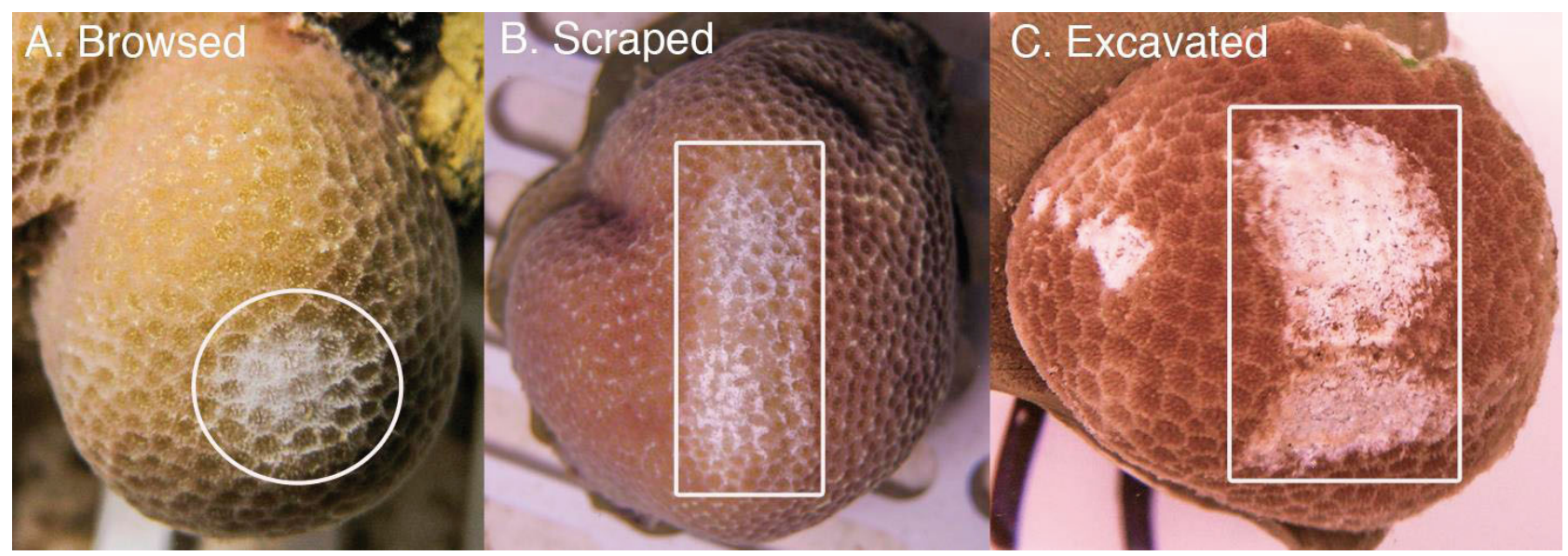

Fig. 1. Photographs of colonies of massive Porites spp. damaged to simulate the effects of fish corallivores. (A) Browser treatment, with only tissue damage; (B) scraper treatment, with tissue and skeletal damage; and (C) excavation treatment, with tissue and deeper skeletal damage. Treatments were designed to mimic damage caused by (A) butterflyfish, (B) parrotfish, and $(\mathrm{C})$ pufferfish. The white circle and boxes mark the approximate margins of the lesions, which had a mean size of $35.0 \pm$ $1.8 \mathrm{~mm}^{2}$ in the browsing treatment, $108.0 \pm 2.5 \mathrm{~mm}^{2}$ in the scraping treatment, and $105.0 \pm 3.2 \mathrm{~mm}^{2}$ in the excavating treatment $( \pm \mathrm{SE}, \mathrm{n}=8)$. Lesions on Pocillopora meandrina (not shown) were similar in size and extent of damage

area-normalized growth was compared between groups with a 1-way ANOVA. A cage-control experiment was not conducted for Pocillopora because we assumed that any effects on Porites were representative of the ways in which our cages would affect other scleractinians.

A total of 32 small $(<5 \mathrm{~cm}$ diameter $)$ colonies of Porites and 32 short $(<7 \mathrm{~cm}$ high) branches from adult Pocillopora were collected from 2 to $3 \mathrm{~m}$ depth in the back reef on 7 April 2009 and prepared as nubbins (Birkeland 1976). Colonies of Porites were collected over $\sim 800 \mathrm{~m}^{2}$ of rock pavement substratum, and branches of Pocillopora were broken from haphazardly selected colonies, with 1 branch colony ${ }^{-1}$ to increase the likelihood that each was genetically unique. Freshly collected corals were transported to the Richard B. Gump South Pacific Research Station and left in flowing seawater until the following day, when they were allocated to one of 4 treatments ( 8 nubbins in each of 4 treatments): undamaged controls; browsed damage (simulating damage caused by chaetodontids; Hiatt \& Strasburg 1960); scraped damage (simulating damage caused by scarids; Bellwood \& Choat 1990); and excavated damage (simulating damage caused by tetraodontids; Bellwood \& Choat 1990). The simulated damage was standardized at a severity that is ecologically relevant to that occurring naturally from fish bites (Cole et al. 2008, Rotjan \& Lewis 2008). Visual surveys in the back reef confirmed that the simulated bites were similar in size and shape to those caused naturally by fishes on the same corals (C. M. Cameron unpubl. data). It was not feasible to use live fish to administer standardized damage in an experimental context.

The damage caused by browsing fishes was simulated using a narrow stream of pressurized seawater from a $60 \mathrm{ml}$ syringe to strip away the tissue in a circular area $\sim 6$ to $7 \mathrm{~mm}$ in diameter without damaging the skeleton (Fig. 1A). This technique simulated the removal of polyps alone, and their removal was confirmed using a dissecting microscope in preliminary trials. It proved difficult to find natural lesions on corals on the reef that could be unequivocally attributed to browsing fishes (Lenihan et al. 2011), and therefore we scaled our simulated browsed lesions to match those simulated on Favia favus and massive Porites spp. (Oren et al. 1997a, van Woesik 1998). Removing tissue and underlying skeleton to 1-2 mm depth represented damage in the scraped treatment, and in the excavated treatment, tissue and skeleton were removed to $2-5 \mathrm{~mm}$ depth. For scraped and excavated treatments, damage was created using $10 \mathrm{~mm}$ wide snub-nose pliers to abrade a lesion $\sim 14 \times$ $7 \mathrm{~mm}$ (Fig. 1B,C). One limitation of the aforementioned methods of damaging corals is that they create margins to the damaged areas that are more linear than those found in nature because of actual fish corallivory. Immediately following damage, the area of damage in the scraped and excavated treatments was similar in size to lesions caused naturally by fishes in the equivalent functional feeding guild in Moorea (C. M. Cameron unpubl. data). On the back reef, the mean area of lesions created by fishes in the scraping and excavating feeding guilds on Porites 
and Pocillopora was $95 \pm 3 \mathrm{~mm}^{2}( \pm \mathrm{SE}, \mathrm{n}=369)$, whereas the mean size of lesions simulating these effects was $106 \pm 2 \mathrm{~mm}^{2}( \pm \mathrm{SE}, \mathrm{n}=32$, this experiment). The pliers were carefully rinsed in clean seawater between damaging each coral, and we assume this prevented cross contamination of mucous and bacteria among corals.

In all treatments, damage was administered as a single 'bite' on the top of each coral because this is where most bites occur on branches of Pocillopora meandrina in the field (Cole et al. 2008). The standardized location prevented position effects from influencing healing (Meesters et al. 1992, Meesters \& Bak 1995), and the single area of damage mimicked focused fish biting (Bruckner et al. 2000). Following damaging, corals were glued (Z-Spar A788) to plastic bases to create nubbins and the size (length $\times$ width) of the damaged areas measured using calipers $( \pm 1 \mathrm{~mm})$. Lesion area (i.e. size) was calculated geometrically assuming the lesions were rectangular, and the initial weight of the corals was recorded by buoyant weighing ( $\pm 1 \mathrm{mg}$, Davies 1989).

On 9 April 2009, corals were transported to the back reef and allocated haphazardly to cement blocks at 2 to $3 \mathrm{~m}$ depth in a single contiguous area $(\sim 5 \times 5 \mathrm{~m})$, where they remained for $21 \mathrm{~d}$. When the experiment was conducted, the mean temperature of ambient seawater was $29.00 \pm 0.02^{\circ} \mathrm{C}( \pm \mathrm{SE}, \mathrm{n}=21 \mathrm{~d})$, and at this depth the maximum light intensity in April typically is $\sim 1200 \mu \mathrm{mol}$ photons $\mathrm{m}^{-2} \mathrm{~s}^{-1}$ (at noon on a sunny day as measured with a LiCor LI 193SA sensor) (Edmunds \& Lenihan 2010). Each cinderblock held 2 replicate corals of the same taxon and same treatment group (control, browsed, scraped, or excavated) and was entirely enclosed in a plastic-coated wire cage to exclude fish and allow passage of seawater; cages were cleaned of algae every other day. The allocation of corals to cages supported a statistical design (described below) in which the effect of cages was nested in the treatment $x$ taxon interaction.

Growth rates were evaluated as change in weight of the corals between the initial and final buoyant weight $( \pm 1 \mathrm{mg})$. Change in buoyant weight was converted to dry weight using the density of aragonite (2.93 $\mathrm{g} \mathrm{cm}^{-3}$, Jokiel et al. 1978). Following the final weighing on 30 April 2009, if lesions were visually detectable, they were again measured using calipers (length and width), and the difference between initial and final lesion size was expressed as a percentage of the initial lesion size to quantify healing. Finally, corals were dried at $70^{\circ} \mathrm{C}$ for $\sim 48 \mathrm{~h}$ and the surface area formerly occupied by live tissue measured by either wax dipping (Stimson \& Kinzie 1991) for Pocillopora or covering with aluminum foil (Marsh 1970) for Porites. Growth rates were normalized to area and time and expressed as $\mathrm{mg} \mathrm{cm}^{-2} \mathrm{~d}^{-1}$.

As the deposition of skeleton results in both corallum growth and the healing of scraping and excavating damage (where administered), it was not possible in this experiment to distinguish skeletal growth of the undamaged portion of the corallum from healing at the site of the lesion. In a separate study, we used Alizarin dye (Cameron 2011) to evaluate where on the surface of coral colonies growth occurs following damage, and these results are reported elsewhere (Cameron 2011).

\section{Statistical analysis}

The effect of caging on Porites (the procedural control) was analyzed using a 1-way ANOVA with growth as the dependent variable. To test for differences in growth and lesion healing among treatments, partially nested ANOVAs were used, in which treatment (scraped, excavated, and browsed, with controls included in the analysis of growth) and taxon (Porites versus Pocillopora) were fixed effects, and cage was a random effect nested within the treatment $\times$ taxon interaction. Where the cage effect was not significant at $\mathrm{p}>0.25$, it was dropped from the statistical model (Quinn \& Keough 2002) and the analysis repeated as a 2-way ANOVA using corals as replicates. Taxon was treated as a fixed effect, since taxa were chosen to contrast imperforate and perforate skeletons. Percentage lesion healing was arcsine transformed prior to analyses and the statistical assumptions of ANOVA (normality and homoscedasticity) tested through graphical analyses of residuals. Tukey's post hoc procedures for each species were used to test for differences among treatment groups for growth rates. For lesion healing, there was a significant effect of cage (i.e. corals responded to treatments in slightly different ways on each block; described below), and thus we conducted post hoc analyses following the output of the nested ANOVA model instead of separate post hoc analyses by species. Statistical analyses were completed using Systat Version 12 software.

\section{RESULTS}

In the procedural control, there was no effect of caging on the growth of Porites $(F=0.097, \mathrm{df}=1,17$, $\mathrm{p}=0.759$ ), and the corals appeared normal in color 
with an absence of excess mucus production. Uncaged corals grew $2.52 \pm 0.14 \mathrm{mg} \mathrm{cm}^{-2} \mathrm{~d}^{-1}$, and caged corals grew $2.59 \pm 0.20 \mathrm{mg} \mathrm{cm}^{-2} \mathrm{~d}^{-1}$ (both $\pm \mathrm{SE}$, $\mathrm{n}=10$ ).

Most damaged corals produced a thin layer of mucus over the lesion within $\sim 12 \mathrm{~h}$ of damage, with excavation damage associated with more mucus production than the other 2 corallivory treatments. Within $2 \mathrm{~d}$ of damaging and after the corals had been returned to the reef, excess mucus production ceased. Approximately $4 \mathrm{~d}$ after damage, the tissue bordering most lesions (regardless of treatment type) formed a thin, pale yellow band, and at the same time, a normal brown/green color started to appear in the center of the lesions. After $10 \mathrm{~d}$, the margins of all lesions were still visible as a narrow band of pale tissue, especially in the corals subjected to scraping and excavation damage. Even though signs of healing were seen on all damaged corals at the end of the experiment, the perimeters of the original lesion remained visible, and the healed tissue was marked by subtle discoloration or surface irregularities. Overall, only one of the 64 experimental corals (one Porites in the control group) died during the experiment. By the end of the study, 3 Pocillopora corals (1 coral from each damage treatment) and 1 Porites colony had small patches $\left(\sim 2 \mathrm{~mm}^{2}\right)$ of filamentous algae overgrowing a portion of the original lesion.

Corals in all treatments increased in dry weight between 650 and $1136 \mathrm{mg}$ for Porites and between 289 and $755 \mathrm{mg}$ for Pocillopora, and area-normalized growth rates ranged from $1.72 \pm 0.12$ to $2.83 \pm$ $0.15 \mathrm{mg} \mathrm{cm}^{-2} \mathrm{~d}^{-1}$ for Porites and from $0.99 \pm 0.08$ to $2.15 \pm 0.09 \mathrm{mg} \mathrm{cm}^{-2} \mathrm{~d}^{-1}$ for Pocillopora. Moreover, mean growth rates of Porites were 24, 42, 43, and $27 \%$ faster than mean growth rates of Pocillopora in the control, excavated, scraped, and browsed treatments, respectively (Fig. 2). Corals in the control group grew faster than those in the 3 damage treatments, and excavated corals had the slowest growth rate (Fig. 2). Compared to the controls, mean growth rates of Porites were reduced $39 \%$ in the excavated treatment, $24 \%$ in the scraped treatment, and $13 \%$ in the browsed treatment; mean growth rates of Pocillopora were reduced $54 \%$ in the excavated treatment, $42 \%$ in the scraped treatment, and $17 \%$ in the browsed treatment. Growth rates differed among treatments and taxa, and there was no taxon $\times$ treatment interaction and no effect of caging (Table 1, Fig. 2). For Pocillopora, post hoc analyses revealed that all treatments differed from one another $(\mathrm{p} \leq$ $0.001)$, except for the excavated versus scraped comparison $(\mathrm{p}=0.209)$. For Porites, growth differed

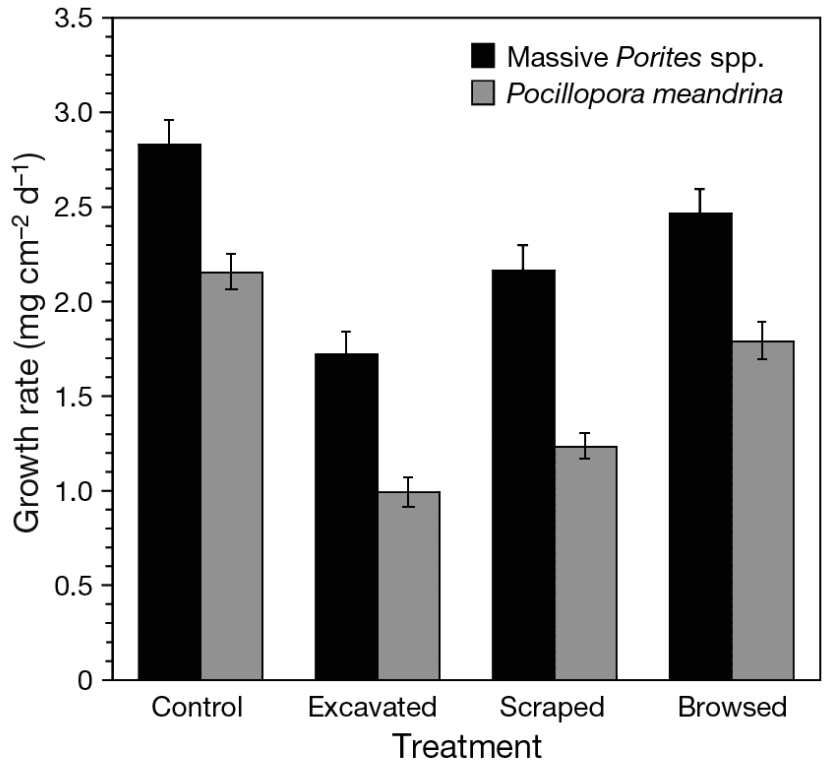

Fig. 2. Growth rates $\left(\mathrm{mg} \mathrm{cm} \mathrm{cm}^{-2} \mathrm{~d}^{-1}\right.$ ) of massive Porites spp. and Pocillopora meandrina after $21 \mathrm{~d}$ in each treatment. Values plotted are mean $\pm \mathrm{SE}(\mathrm{n}=7$ control; $\mathrm{n}=8$ all others $)$

Table 1. Results of partially nested ANOVA comparing growth over $21 \mathrm{~d}$ for massive Porites spp. and Pocillopora meandrina (Taxon) exposed to control, browsed, scraped, or excavated damage (Treatment). The effects of taxon, treatment, and the interaction between them were tested over $\mathrm{MS}_{\text {error, }}$ as the cage effect was not significant and was dropped from the model

\begin{tabular}{|lcrrr|}
\hline Source & MS & df & $F$ & \multicolumn{1}{c|}{ p } \\
\hline Taxon & 8.927 & 1 & 96.841 & $<0.001$ \\
Treatment & 3.820 & 3 & 41.443 & $<0.001$ \\
Treatment $\times$ Taxon & 0.059 & 3 & 0.638 & 0.594 \\
Error & 0.092 & 55 & & \\
\hline
\end{tabular}

among all treatments $(\mathrm{p}<0.001)$, except for the control versus browsed $(\mathrm{p}=0.223)$, excavated versus scraped $(\mathrm{p}=0.083)$, and scraped versus browsed $(\mathrm{p}=$ 0.352) comparisons.

Most lesions showed at least some signs of healing, but the percentage of each lesion that healed differed among treatments and taxa (Table 2, Fig. 3). On average, lesions on Pocillopora healed $22 \%$ more than lesions in the same treatment group on Porites, except for excavated lesions (Fig. 3). Excavated lesions on Porites healed $\sim 10 \%$ more than those on Pocillopora. The difference in mean healing extent was $\sim 50 \%$ for Pocillopora and $\sim 20 \%$ for Porites for the least destructive mode of damage (i.e. browsing) versus the most destructive mode of damage (i.e. excavation) (Fig. 3). The post hoc analyses following 
Table 2. Results of partially nested ANOVA comparing the percentage that lesions healed (arcsine transformed) over $21 \mathrm{~d}$ for massive Porites spp. and Pocillopora meandrina (Taxon) exposed to browsed, scraped, or excavated damage (Treatment). The effects of Taxon, Treatment, and the interaction between them were tested over $\mathrm{MS}_{\text {cage(Treatment } \times \text { Taxon) }}$

\begin{tabular}{|lcrrr|}
\hline Source & MS & df & \multicolumn{1}{c}{$F$} & \multicolumn{1}{c|}{$\mathrm{p}$} \\
\hline Taxon & 0.355 & 1 & 5.220 & 0.034 \\
Treatment & 0.991 & 2 & 14.573 & $<0.001$ \\
Treatment $\times$ Taxon & 0.209 & 2 & 3.074 & 0.071 \\
Cage (Treatment $\times$ Taxon) & 0.068 & 18 & 2.429 & 0.021 \\
Error & 0.028 & 24 & & \\
\hline
\end{tabular}

the nested ANOVA suggest that the percent that each lesion healed in each damage treatment (i.e. browsed, scraped, excavated), regardless of species, was significantly different from one another ( $\mathrm{p} \leq$ 0.001 for all comparisons). Based on the percent that lesions healed, the treatments ranked as browsed > scraped $>$ excavated (Fig. 3). The extent of healing also differed among cages (within taxon $\times$ treatment) (Table 2), but the taxon $\times$ treatment interaction was not significant (Table 2, Fig. 3).

\section{DISCUSSION}

The effects of localized damage on reef corals are relatively well known, usually in response to one type of mechanical damage (Nagelkerken \& Bak 1998, Lirman 2000, Rotjan \& Lewis 2005, Jayewardene et al. 2009, Edmunds \& Lenihan 2010, Jayewardene 2010). Fish corallivores and the tissue and skeleton they remove are one of the best-known sources of damage to coral colonies (Reyes-Bonilla \& Calderon-Aguilera 1999, Berumen \& Rotjan 2010, Cole et al. 2011). A small number of studies have explored the effects of multiple types of damage on corals, but even in these cases, the underlying mechanisms responsible for the responses of the coral to damage have not been extensively studied (but see Oren et al. 1997a,b, 2001). Our results show that under field conditions, corals were able to heal lesions and continue growing following all types of simulated damage, but the amount of healing and growth depended on the degree of damage and the coral species. Although corallivory may not be an immediate threat to coral populations given global increases in temperature and ocean acidification conditions, in at least one location, the abundance of small corals is negatively correlated with the abundance and biomass of browsing, scraping, and exca-

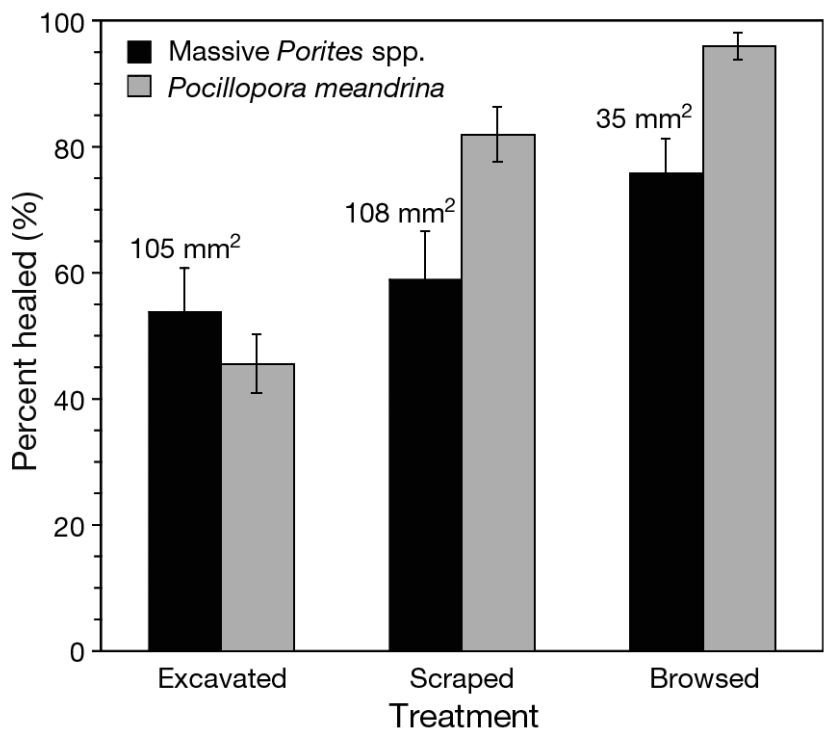

Fig. 3. Percentage of each lesion healed after $21 \mathrm{~d}$ for massive Porites spp. and Pocillopora meandrina in each treatment group. Values plotted are the mean \pm SE $(n=8)$; numbers above each treatment represent the average initial lesion area $\left(\mathrm{mm}^{2}\right)$ on corals in both taxa

vating corallivores (Penin et al. 2010, Trapon et al. 2013). Therefore, comparisons of the effects of multiple types of simulated corallivory on coral performance are likely to be relevant to understanding the causes of changes in coral community structure.

There are at least 3 hypotheses that can account for the differences in growth and healing in Porites versus Pocillopora, as well as the differences in healing among modes of damage (i.e. types of corallivory). First, the effect of taxon in mediating differences in tissue healing following damage may reflect variations in the capacity for translocation of metabolites within colonies (Oren et al. 1997b, 2001). For scleractinians to heal tissue damaged within lesions, the damaged margin of the tissue must be repaired, and tissue must be produced to occupy the lesion. In addition to repairing and replacing tissue, skeleton may also need to be produced when damage affects the skeleton as well (i.e. as in scraping and excavation treatments). Together these processes require raw materials (e.g. proteins and carbohydrates) and metabolic energy to meet the costs of biochemical work (Henry \& Hart 2005), and in corals containing Symbiodinium, these needs ultimately are supplied by heterotrophic feeding, photosynthesis, and food reserves (Muscatine 1990, Houlbreque \& FerrierPages 2009). Additionally, $\mathrm{Ca}^{2+}$ and dissolved inorganic carbon (DIC) required for skeletogenesis can come from the surrounding seawater, with additional DIC drawn from the internal environment of the coral 
(Swart et al. 1996, Grottoli \& Wellington 1999, Furla et al. 2000).

Sources of the metabolites necessary to support healing in corals can be found in regions of the colony separate from the site of damage, and therefore the capacity to translocate metabolites to the site of use can influence healing (Oren et al. 1997b). In long-lived corals that are colonial and sessile, healing can be prioritized over growth and reproduction for energy allocation (Hall 1997, Oren et al. 2001) because its benefits accrue over the life span. Motility is not an option to avoid damage (Jackson 1979), and it is less costly to heal damaged polyps than to produce new polyps (Hall 2001). Although browsed corals healed faster than excavated corals (Fig. 3), the size of this effect was small, especially for Porites. Perhaps for a slow-growing coral like massive Porites spp. that settles in lower abundance than Pocillopora spp. in Moorea (e.g. Penin et al. 2010), there is a benefit to healing a severe wound (consisting of damage to skeleton and tissue) almost as quickly as healing a less severe wound (i.e. consisting of only tissue damage), to reduce the time that skeleton is exposed to seawater and the period over which metabolites must be diverted to heal the damage.

Second, it is possible that skeletal porosity modulates recovery from fish corallivory, with the differences in porosity between Porites (perforate) versus Pocillopora (imperforate) favoring differential recovery from damage. Covarying with skeletal porosity is the extent to which coral tissue permeates the skeleton, with this effect well developed in Porites (Barnes \& Lough 1992) but minimal in Pocillopora. The penetration of tissue into the skeleton has a variety of consequences (Jokiel et al. 1993, Santos et al. 2009, Edmunds et al. 2012), but in the context of the present study, its role in affecting the capacity to heal damage might lie in providing access to photosynthetically fixed carbon translocated from Symbiodinium spread throughout a large volume of tissue (Edmunds et al. 2012). Additionally, tissue deep within coral skeletons may be inaccessible to most corallivorous fishes, and even a gouging fish bite potentially can leave coral tissue within the skeleton. Residual tissue might then serve as a reservoir of interstitial cells (sensu Jokiel et al. 1993) that could support healing of tissue.

In contrast to Porites, Pocillopora has an imperforate skeleton with superficial tissue (Tricas 1989) and thus must rely on events occurring at the margins of lesions to effect repair. While an imperforate skeleton is associated with reduced ability of Pocillopora to endure excavation damage (which removes skele- ton and tissue), an imperforate skeleton may increase the ease with which browsing and scraping damage can be healed simply because less tissue is lost with an equal area of damage on Pocillopora versus Porites (Edmunds et al. 2011). Although skeletal porosity provides a testable hypothesis to account for at least some of the differences in the capacity to heal in Porites versus Pocillopora, in the present analysis, this effect is confounded by corallum morphology, which also differed between taxa. Further studies of healing in corals differing in skeletal porosity but not corallum morphology would be valuable in resolving these effects.

Finally, the variation in response to damage simulating different feeding guilds of fish corallivores may be caused by lesion allometry, which differs among the types of lesions (Bak \& Steward-Van Es 1980, Meesters \& Bak 1995, Oren et al. 1997a,b, Jayewardene 2010). As lesion types differ in size, perimeter shape, and the extent to which they penetrate the skeleton, the ratios of damaged area and volume to the area and perimeter of tissue marginal to the lesion are variable. Additionally, the ratio of area damaged to area of intact tissue on the remainder of the colony differs with colony size, as this could affect the capacity to heal (Oren et al. 1997a) by modulating the potential for more distant tissues to supply metabolites to the site of damage.

Variation in lesion size among treatments may account for the difference in recovery of the present corals because browsing lesions were only $31 \%$ of the area of scraping and excavating lesions when first created. The rate of healing of lesions inflicted on Porites is slower compared to other corals (i.e. pocilloporids; Hall 1997, van Woesik 1998) regardless of lesion size. Bak \& Steward van Es (1980) found that lesions mimicking the damage caused by browsing and scraping fishes on Porites astreoides healed faster than those inflicted on Agaricia agaricites, but the largest lesions (i.e. $5 \mathrm{~cm}^{2}$ lesions) on both species did not heal fully even after $140 \mathrm{~d}$. Our findings are similar to those of Bak \& Steward van Es (1980) in that our corals did not heal fully from the most severe damage (i.e. tissue and skeleton lesions), but several corals completely recovered from the browser damage. Although we are unable to determine whether browsed corals displayed greater healing capacity because these lesions were small or because they were better able to heal tissue alone versus tissue plus skeleton, as is necessary in corals more severely damaged, our results show that browsed corals healed quickly compared to corals damaged by scraping or excavation. 
Because of the increasing frequency and intensity of both natural and anthropogenic disturbances, coral reefs likely will experience synergistic effects (Gardner et al. 2003), and their survival will be contingent on the extent to which they can recover from such disturbances (Wilson et al. 2006). Disturbances in the last decade caused a decline in coral cover on the outer reef of Moorea from $~ 40 \%$ in 2005 to $<5 \%$ in 2010 (Adam et al. 2011), as well as a shift in coral community composition (Adjeroud et al. 2009). With an increase in reef stressors and a decrease in coral abundance, the role that corallivory plays in influencing coral reef community dynamics may be more complex than previously expected. For example, Penin et al. (2010) showed that corals in Moorea between 1 and $5 \mathrm{~cm}$ in diameter had mean mortality rates between 23 and $39 \%$ over 4 to 14 mo, and mortality at 9 stations was significantly correlated with the abundance of chaetodontid corallivores. In contrast, 18 to $70 \%$ of corals $<3$ mo old (i.e. defined as recruits) died over $1 \mathrm{wk}$, and mortality in this age class at 9 stations was significantly correlated with the abundance of scarid corallivores (Penin et al. 2010). Therefore, populations of coral genera preferred by fish corallivores may be more strongly impacted by these corallivores if coral populations continue to decline while their predators remain abundant, even for corals affected by the least-damaging type of corallivory (i.e. browsing). Although a variety of other biotic and abiotic factors contribute to the success of small corals, the positive correlation of the mortality rate of small corals with the abundance of fish corallivores in Moorea between 2001 and 2006 (Penin et al. 2010) suggests that corallivory continues to play a role in determining coral community dynamics on contemporary reefs. By revealing that the response of small corals to simulated fish corallivory depends on the species of coral, the present study underscores the value of broadening the range of coral species and damage types studied in the context of fish corallivory to better understand the factors contributing to shifts in abundance and diversity of coral species.

Acknowledgements. We thank V. Moriarty, L. Jacobson, S. Davis, S. Swanson, D. H. Green, W. M. Goldenheim, A. Brown, and N. B. Colvard for their help in the field. Funding was provided by the Moorea Coral Reef Long Term Ecological Research (MCR-LTER) program, US National Science Foundation (grants OCE 04-17412 and OCE 10-26851), and gifts from the Gordon and Betty Moore Foundation. This research represents partial fulfillment for the Master of Science degree to C. M. Cameron at California State University, Northridge (CSUN), and it benefited greatly from the advice provided by R. C. Carpenter, M. Steele, and S. Dudgeon throughout all stages of the project. Comments from 4 anonymous reviewers improved an earlier draft of this paper. This is contribution number 214 of the CSUN Marine Biology Program.

\section{LITERATURE CITED}

Adam TC, Schmitt RJ, Holbrook SJ, Brooks AJ, Edmunds PJ, Carpenter R, Bernardi G (2011) Herbivory, connectivity, and ecosystem resilience: response of a coral reef to a large-scale perturbation. PLoS ONE 6:e23717

Adjeroud M, Michonneau F, Edmunds PJ, Chancerelle Y and others (2009) Recurrent disturbances, recovery trajectories, and resilience of coral assemblages on a South Central Pacific reef. Coral Reefs 28:775-780

Allemand D, Benazet-Tambutte S (1996) Dynamics of calcification in the Mediterranean red coral, Corallium rubrum (Linnaeus) (Cnidaria, Octocorallia). J Exp Zool 276: $270-278$

Ayre DJ, Davis AR, Billingham M, Llorens T, Stryan C (1997) Genetic evidence for contrasting patterns of dispersal in solitary and colonial ascidians. Mar Biol 130:51-61

Bak RPM, Steward-Van Es Y (1980) Regeneration of superficial damage in the scleractinian corals Agaricia agaricites f. purpurea and Porites astreoides. Bull Mar Sci 30: 883-887

Bak RPM, Curacao P, Brouns J, Heys FML (1977) Regeneration and aspects of spatial competition in the scleractinian corals Agaricia agaricites and Montastrea annularis. Proc 3rd Int Coral Reef Symp, Miami, 1:143-148

- Barnes DJ, Devereux MJ (1988) Variations in the skeletal architecture associated with density banding in the hard coral Porites. J Exp Mar Biol Ecol 121:37-54

- Barnes DJ, Lough JM (1992) Systematic variations in the depth of skeleton occupied by coral tissue in massive colonies of Porites from the Great Barrier Reef. J Exp Mar Biol Ecol 159:113-128

> Bellwood DR, Choat JH (1990) A functional analysis of grazing in parrotfishes (family Scaridae): the ecological implications. Environ Biol Fishes 28:189-214

> Berumen ML, Pratchett MS (2006) Recovery without resilience: persistent disturbance and long-term shifts in the structure of fish and coral communities at Tiahura Reef, Moorea. Coral Reefs 25:647-653

Berumen ML, Rotjan RD (2010) New records of corallivory in the Red Sea. Coral Reefs 29:727

Birkeland C (1976) An experimental method of studying corals during early stages of growth. Micronesica 12: 319-322

> Bruckner AW, Bruckner RJ, Sollins P (2000) Parrotfish predation on live coral: 'spot biting' and 'focused biting'. Coral Reefs 19:50

Cameron CM (2011) The effects of partial mortality on corals in St. John, U.S. Virgin Islands and Moorea, French Polynesia. Master's thesis, California State University, Northridge, $\mathrm{CA}$

Cole AJ, Pratchett MS (2011) Inter-specific variation in susceptibility to grazing among common reef corals. Mar Ecol Prog Ser 422:155-164

Cole AJ, Pratchett MS, Jones GP (2008) Diversity and functional importance of coral-feeding fishes on tropical coral reefs. Fish Fish 9:286-307

> Cole AJ, Lawton RJ, Pratchett MS, Wilson SK (2011) Chronic 
coral consumption by butterflyfishes. Coral Reefs 30: 85-93

$>$ Davies PS (1989) Short-term growth measurements of corals using an accurate buoyant weighing technique. Mar Biol 101:389-395

Edmunds PJ (2005) The effect of sub-lethal increases in temperature on the growth and population trajectories of three scleractinian corals on the southern Great Barrier Reef. Oecologia 146:350-364

Edmunds PJ (2008) The effects of temperature on the growth of juvenile scleractinian corals. Mar Biol 154: 153-162

Edmunds PJ, Lenihan HS (2010) Effect of sub-lethal damage to juvenile colonies of massive Porites spp. under contrasting regimes of temperature and water flow. Mar Biol 157:887-897

Edmunds PJ, Putnam HM, Nisbet RM, Muller EB (2011) Benchmarks in organism performance and their use in comparative analyses. Oecologia 167:379-390

Edmunds PJ, Putnam HM, Gates RD (2012) Photophysiological consequences of vertical stratification of Symbiodinium in tissue of the coral Porites lutea. Biol Bull 223: 226-235

Furla P, Galgani I, Durand I, Allemand D (2000) Sources and mechanisms of inorganic carbon transport for coral calcification and photosynthesis. J Exp Biol 203:3445-3457

Gardner TA, Cote IM, Gill JA, Grant A, Watkinson AR (2003) Long-term region-wide declines in Caribbean corals. Science 301:958-960

Grottoli AG, Wellington GM (1999) Effect of light and zooplankton skeletal $\delta 13 \mathrm{C}$ values in the eastern Pacific corals Pavona clavus and Pavona gigantea. Coral Reefs 18:29-41

Hall VR (1997) Interspecific differences in the regeneration of artificial injuries on scleractinian corals. J Exp Mar Biol Ecol 212:9-23

Hall VR (2001) The response of Acropora hyacinthus and Montipora tuberculosa to three different types of colony damage: scraping injury, tissue mortality and breakage. J Exp Mar Biol Ecol 264:209-223

> Henry LA, Hart M (2005) Regeneration from injury and resource allocation in sponges and corals - a review. Int Rev Hydrobiol 90:125-158

Hiatt RW, Strasburg DW (1960) Ecological relationships of the fish fauna on coral reefs of the Marshall Islands. Ecol Monogr 30:65-127

> Houlbreque F, Ferrier-Pages C (2009) Heterotrophy in tropical scleractinians corals. Biol Rev Camb Philos Soc 84: $1-17$

Jackson JBC (1979) Morphological strategies of sessile animals. In: Larwood G, Rosen BR (eds) Biology and systematics of colonial organisms. Academic Press, London, p 499-555

Jayewardene D (2010) Experimental determination of the cost of lesion healing on Porites compressa growth. Coral Reefs 29:131-135

Jayewardene D, Donahue MJ, Birkeland C (2009) Effects of frequent fish predation on corals in Hawaii. Coral Reefs 28:499-506

Jokiel PL, Maragos JE, Franzisket L (1978) Coral growth: buoyant weight technique. UNESCO Monogr Oceanogr Methodol 5:529-542

> Jokiel PL, Hunter CL, Taguchi S, Watarai L (1993) Ecological impact of a fresh-water 'reef kill' in Kaneohe Bay, Oahu, Hawaii. Coral Reefs 12:177-184
Lenihan HS, Edmunds PJ (2010) Response of Pocillopora verrucosa to corallivory varies with environmental conditions. Mar Ecol Prog Ser 409:51-63

Lenihan HS, Holbrook SJ, Schmitt RJ, Brooks AJ (2011) Influence of corallivory, competition, and habitat structure on coral community shifts. Ecology 92:1959-1971

Lirman D (2000) Lesion regeneration in the branching coral Acropora palmata: effects of colonization, colony size, lesion size, and lesion shape. Mar Ecol Prog Ser 197: 209-215

Lough JM, Barnes DJ (2000) Environmental controls on growth of the massive coral Porites. J Exp Mar Biol Ecol 245:225-243

Marsh JA (1970) Primary productivity of reef-building calcareous red algae. Ecology 51:255-263

Meesters EH, Bak RPM (1995) Age-related deterioration of a physiological function in the branching coral Acropora palmata. Mar Ecol Prog Ser 121:203-209

Meesters EH, Bos A, Gast GJ (1992) Effects of sedimentation and lesion position on coral tissue regeneration. Proc 7 th Int Coral Reef Symp, Guam, 2:671-678

> Meesters EH, Wesseling I, Bak RPM (1997) Coral colony tissue damage in six species of reef-building corals: partial mortality in relation with depth and surface area. J Sea Res 37:131-144

Muscatine L (1990) The role of symbiotic algae in carbon and energy flux in reef corals. In: Dubinsky Z (ed) Coral reefs. Ecosystems of the world, Vol 25. Elsevier, Amsterdam, p 75-87

Nagelkerken I, Bak RPM (1998) Differential regeneration of artificial lesions among sympatric morphs of the Caribbean corals Porites astreoides and Stephanocoenia michelinii. Mar Ecol Prog Ser 163:279-283

Oren U, Benayahu Y, Loya Y (1997a) Effect of lesion size and shape on regeneration of the Red Sea coral Favia favus. Mar Ecol Prog Ser 146:101-107

Oren U, Rinkevich B, Loya Y (1997b) Oriented intra-colonial transport of ${ }^{14} \mathrm{C}$ labeled materials during coral regeneration. Mar Ecol Prog Ser 161:117-122

> Oren U, Benayahu Y, Lubinevsky H, Loya Y (2001) Colony integration during regeneration in the stony coral Favia favus. Ecology 82:802-813

> Penin L, Michonneau F, Baird AH, Connolly SR, Pratchett MS, Kayal M, Adjeroud M (2010) Early post-settlement mortality and the structure of coral assemblages. Mar Ecol Prog Ser 408:55-64

Pratchett MS (2013) Feeding preferences and dietary specialization among obligate coral-feeding butterflyfishes. In: Pratchett MS, Berumen ML, Kapoor BG (eds) Biology of butterflyfishes. CRC Press, Boca Raton, FL, p 140-179

> Pratchett MS, Trapon M, Berumen ML, Chong-Seng K (2011) Recent disturbances augment community shifts in coral assemblages in Moorea, French Polynesia. Coral Reefs 30:183-193

Quinn GP, Keough MJ (2002) Experimental design and data analysis for biologists. Cambridge University Press, Cambridge

> Reyes-Bonilla H, Calderon-Aguilera LE (1999) Population density, distribution and consumption rates of three corallivores at Cabo Pulmo Reef, Gulf of California, Mexico. Mar Ecol 20:347-357

> Rotjan RD, Dimond JL (2010) Discriminating causes from consequences of persistent parrotfish corallivory. J Exp Mar Biol Ecol 390:188-195

> Rotjan RD, Lewis SM (2005) Selective predation by parrot- 
fishes on the reef coral Porites astreoides. Mar Ecol Prog Ser 305:193-201

Rotjan RD, Lewis SM (2008) Impact of coral predators on tropical reefs. Mar Ecol Prog Ser 367:73-91

Rotjan RD, Lewis SM (2009) Predators selectively graze reproductive structures in a clonal marine organism. Mar Biol 156:569-577

Santos SR, Toyoshima J, Kinzie RA III (2009) Spatial and temporal dynamics of symbiotic dinoflagellates (Symbiodinium: Dinophyta) in the perforate coral Montipora capitata. Galaxea J Coral Reef Stud 11:139-147

Stimson JS (1987) Location, quantity and rate of change in quantity of lipids in tissue of Hawaiian hermatypic corals. Bull Mar Sci 41:889-904

Stimson J, Kinzie RA III (1991) The temporal pattern and rate of release of zooxanthellae from the reef coral Pocillopora damicornis (Linnaeus) under nitrogen-enrichment and control conditions. J Exp Mar Biol Ecol 153:63-74

Swart PK, Leder JJ, Szmant AM, Dodge RE (1996) The ori-

Editorial responsibility: Brian Helmuth,

Nahant, Massachusetts, USA gin of variations in the isotopic record of scleractinian corals: II. Carbon. Geochim Cosmochim Acta 60:28712885

> Trapon ML, Pratchett MS, Hoey AS (2013) Spatial variation in abundance, size and orientation of juvenile corals related to the biomass of parrotfishes on the Great Barrier Reef, Australia. PLoS ONE 8:e57788

Tricas TC (1989) Prey selection by coral-feeding butterflyfishes: strategies to maximize the profit. Environ Biol Fishes 25:171-185

van Woesik R (1998) Lesion healing on massive Porites spp. corals. Mar Ecol Prog Ser 164:213-220

> Vermeij MJA, Sandin SA (2008) Density-dependent settlement and mortality structure the earliest life phases of a coral population. Ecology 89:1994-2004

Wilson SK, Graham NAJ, Pratchett MS, Jones GP, Polunin NVC (2006) Multiple disturbances and the global degradation of coral reefs: Are reef fishes at risk or resilient? Glob Change Biol 12:2220-2234

Submitted: November 11, 2013; Accepted: May 14, 2014 Proofs received from author(s): July 13, 2014 